Teklie, T.B., The Status of Democratic Developmental State in Ethiopia: Is It Rolling Back ...

\title{
The Status of Democratic Developmental State in Ethiopia: Is It Rolling Back or Rolling Forward?
}

Teklie Tesfamariam Berhe*

\begin{abstract}
The Democratic Developmental State (DDS) model was attempted during the tenure of the Ethiopian Peoples' Revolutionary Democratic Front's (EPRDF) in Ethiopia. In this paper, an effort has been made hence to explore some economic blessings and political curses incurred, cases for launching and now terminating DDS, and the reform-led changes and continuities in the political economy of Ethiopia. In doing so, the researcher has depended on a qualitative approach and in-depth content analysis of secondary data sources. The finding revealed that the ideological confrontations and lusts for power coupled with the fragile institutional and structural profiles of the EPRDF-led government have precipitated the abortion of the embryonic DDS. Indeed, in the pursuit of DDS, a trade-off between promoting democracy and achieving economic development has remained at a tolerable cost. In consequence, protracted popular grievances against the unequal distribution of benefits have been accompanied by paving the birth of a new leadership submissive to the Neo-Liberal recipes. Now, the state seems as it goes to start from scratch despite some belief that the new leadership appears to regurgitate the footsteps of its predecessor EPRDF rebranding the infamous legacy. It has been found that the reformist part of the government has been facing coordination problems to materialize the political and economic reforms. To this effect, early costs of the beginnings of the reform have been encountered. For that reason, the researcher suggests that the incumbent government should constitutionally and inclusively overcome the state-wide leadership crisis to ensure positive synergy.
\end{abstract}

Keywords: Democratic Developmental State, Ethiopia, Prosperity Party, Reform

\section{Introduction}

States have played central economic roles in achieving social transformation. Nevertheless, the conventional notion of interventionist state in its present context has been boldly seen in the late $20^{\text {th }}$ century during which the unprecedented and remarkable level of economic growth is experienced in East and Southeast Asian countries such as Japan, South Korea, Taiwan, Singapore, Hong Kong, Malaysia, China and others (Bagchi, 2000; White, 2006; United Nations [UN], 2011; Routley, 2014). Consequently, the old and pragmatic dictum of "no one size fits all" has helped for the adoption and installation of the developmental state model in different socioeconomic and political scenes (Fisseha and Abtweld, 2017).

\footnotetext{
*Adigrat University, Ethiopia. Email: teklietesfa27@gmail.com
} 
Following the end of the cold war, the state-led development model-pursuant Latin American, Asian, and Sub-Saharan African countries were advised to adopt the notorious Structural Adjustment Programs /SAPs/ (Stiglitz, 1998). To this effect, the mere application of Washington Consensus's prescriptions devoid of installing internal necessary governance, institutional and legal frameworks failed to bring about broad-based and ethical development (Pillay, 2002; Bigman, 2007; Rapley, 2010; Asnake, 2011). For this reason, some Less Developed Countries (LDCs) have been engaged in soul searching for another best alternative development path under which they can allocate national resources effectively and efficiently (Stiglitz, 1998). During the states' endeavors, the fashion of the Developmental State (DS) model which enabled the Asian Tigers and some Latin American countries to exhibit a miracle in their economic transformations for about three decades and hitherto has secured attentions and enjoyed precedence (Asnake, 2011).

DS is placed in between the market and plan-rational state seeking to exploit the respective strengths of the market and public sector in securing economic development (Bolesta, 2007). Commonly, DS is identified by the elements of development-oriented leadership, competent and insulated state bureaucracy, production-oriented private sectors, and performance-oriented governance (Musamba, 2010; Tapscot, Halvorsen, and Rosario, 2018). Thus, a typical DS must possess two imperative components: ideological and structural ones. Ideologically, the government leaders' common anthems and practices are required to be ensuring development and eradicating poverty (Mkandawire, 2001). Structurally, DS must enrich with necessary hardware mainly institutional capacities to autonomously implement the development policies in favor of the public interests (Mkandawire, 2001; Fisseha and Abtweld, 2017).

Recognizing the authoritarian nature of the traditional DS, government leaders, policymakers, and scholars sought to see the democratic form of it (Edigheji, 2005). A Democratic Developmental State (DDS) is, therefore, an authoritative, legitimate, autonomous, credible, and strong state to make and enforce its development policies and programs successfully (Edigheji, 2010). In this regard, it is indispensable to mention African democratic developmental attempts of Botswana, Mauritius, Ethiopia, Rwanda, and South Africa (Gedion, 2005; Fesseha and Abtewold, 2017; Clapham, 2018; Tapscot et al., 2018; Hauge and Chang, 2019). 
During the power tenure of EPRDF, Ethiopia has commenced its democratic developmental path to mean that it was aspiring not merely to be developmental but also democratic in the multinational federal contexts. As a matter of commitment, the government has exhibited to reconcile the aforementioned goals reflecting in its consecutive development policy objectives (Eyob, 2017). Undeniably, with all its associated shortcomings including rampant corruption, the economic performance has been a major source of political legitimacy and thus stability in the state (Mehari, 2019). The infrastructural developments, such as the construction of roads, air corridors, railways and buildings, energy generation, housing, provision of health and education, and associated job creation have been relatively entertained (Fesseha and Bizuayehu, 2017; Bereket, 2018; Clapham 2018).

Notwithstanding the economic achievements, there have been popular grievances unleashed from the increasingly undemocratic and rent-seeking behaviors of the party in power which led lastly EPRDF to become the victim of its success (Fesseha and Abtewold, 2017; Government of Regional State of Tigrai, 2020). For the last four years, the state is being identified by the prevalent political turmoil. The quest for good governance coupled with the entrenched leadership crisis in the government forced the people, particularly, the youth to seek political and economic reforms. As a consequence, change in the political leadership was a must whereby the deceased EPRDF gave birth to Prosperity Party (PP). A Neo-liberalism-friendly new leadership led by PP has appeared to seize the state power. In the attempt of understanding the dynamics, changes, and continuities related to Ethiopian DDS, the researcher has reviewed literature devoted to the issues under discussion.

Among others, while Jebena (2015) has studied the incompatibility between developmental state and Ethiopian ethnic federalism, Gedion (2015) has only tried to make a comparative analysis on emerging democratic developmental states of South Africa and Ethiopia. Mulu and Daba (2017) on their part have studied the nature of Ethiopian DDS and found that it is dominantly developmental but emerging. Moreover, Fesseha and Abtewold (2017) defended that the DDS paradigm has helped the state as a weapon in the fight against the common enemy, poverty. Alex de Waal (2018) has also shown his doubt that the state is more likely to be the political marketplace of other countries, particularly the USA, Saudi Arabia, UAE, and Egypt. Furthermore, Tapscott et al. (2018) have analyzed the DDS paradigm from the North-South perspective implying that it differs as per the country-specific contexts. Lastly, Ayele (2018) has 
scholarly examined the existence of the developmental state in Ethiopia merely from economic perspectives. Yet, none of the aforementioned authors has flashed light on the current status of DDS ideals substantiating with the emerging realities that occurred in the political economy of Ethiopia where the aim of this study lays on. Therefore, the general objective of the study is to explore the status of the democratic developmental state indicating whether it is rolling back or rolling forward following the current political dynamics in Ethiopia. In the light of general objective, the research aims to realize the following specific objectives: i) To examine the reasons for pursuing the DDS model and associated blessings and curses incurred in Ethiopia, ii) To analyze the aggravating realities for aborting the DDS model in Ethiopia, and iii) To assess some of the reform led changes and continuities in Ethiopia.

\section{Research Methodology}

This article supplements the existing discourse on the subject of DDS by critically exploring the ongoing politico-economic realities and dynamics experienced in Ethiopia. It has utilized a qualitative approach. Accordingly, secondary data that were collected through a thorough review of books, journal articles, reports, official documents, and credible internet sources have been qualitatively interpreted and analyzed. During reviewing the secondary data and consultation of the issue-specific literature, a content-based in-depth analysis method has also been employed. Hence, the study has covered the socio-economic and political dynamics encountered since the time EPRDF installed DDS and the realities followed due to the recent reform within the incumbent government hitherto.

\section{Review of Related Literature}

\section{The Advent of Ethiopian Democratic Developmental State: The Conditions}

Following the demise of the military regime of Derg in 1991, the forcefully triumphed EPRDF has attempted to employ radical state and nation-building strategies in Ethiopia. From the outset, cognizant of the fact that lifelong intra-state conflicts were caused by the then employed irrelevant policies of the imperial and Derg regimes; EPRDF has brought about some unprecedented organizing principles (Addisalem, 2014). In doing so, in July 1991 EPRDF and others which are about twenty-six political organizations had established the Transitional Government of Ethiopia (TGE) and the subsequent Charter convening the Peace and Democracy Conference (TGE, 1991). 
Among other things, establishing a constitutional commission, the charter was a seedbed for the making of the Federal Democratic Republic of Ethiopia's (FDRE's) Constitution. In accordance, the FDRE constitution has enshrined that the state is a republic, federal, democratic, parliamentarian, and aspired to the free-market system in the long run. More importantly, recognizing the two most popular nationality and land questions, EPRDF has tried to respond to the entrenched mass grievances in Articles 39 and 40 of the FDRE constitution respectively though there are continuing controversies hitherto. Despite the fact that the initial commitment of EPRDF was to conform to the free-market economic system, eventually, it has become proactive in soul searching for relevant alternative development path due to the dead ends of Neo-liberal political economy in the LDCs (Meles, 2012; Jebena, 2015).

Then, in the endeavor of altering the extreme poverty image of the state, the EPRDF led government had been engaged in planning and implementing development policies and strategies. In the early 1990s, the government had set Agricultural Development Led Industrialization (ADLI) to foster agro-processing industries. The other consecutive development policies and strategies include Sustainable Development and Poverty Reduction Program (SDPRP 2001/02-2004/05), Plan for Accelerated and Sustainable Development to End Poverty (PASDEP 2005/06-2009/10), Growth and Transformation Plan (GTP) I (2010/11-2014/15), and GTP II (2015/2016-2019/20) have exhibited the strong aspiration of the government to make the state one of the middle-income countries by 2025 pursuing the DDS path (Eyob, 2017; Fisseha and Abtewold, 2017, Hauge and Chang, 2019). To strengthen, Kenichi Ohno has put the basic condition for undertaking such a development path as follows:

By adopting DDS, Ethiopia intends to radically transform the state management paradigm politically and economically from the system in which rent-seeking is the overriding behavioral pattern to the system where value creation is dominant despite no ground-breaking change is entertained in the fight against the rentseeking government (Ohno, 2009, p.1).

Apart from this, Clapham (2013 as cited in Weldeabrha, 2014) has underlined that there are four conditions for emulating the DS paradigm in Ethiopia. The first is the Ethio-Eritrean war in the sense that it enabled the cooperation of all nations, nationalities, and peoples to struggle against whatever their common enemy including poverty. Secondly, the sharp split within the Tigray 
Peoples' Liberation Front (TPLF) in which the party leaders who were in support of PM Meles Zenawi had conducted revival motions and declared the commencement of DS of Ethiopia. Third, the irritating result of the 2005 general election was an alarming bell for the ruling party to introduce new developmental policies and programs to win over the peoples' hearts and secure legitimacy. Fourth, the personal traits of Meles through which he had highly engaged in rectifying the failures reflected during the Ethio-Eritrean war and 2005 election realized the search for a relevant political economy paradigm.

To add more, Gedion (2015) has also provided other factors that the dead-end of Neo-liberalism is the case for replicating DS in Ethiopia. The late PM Meles had noted Neo-liberalism had already contained functioning efficiently in Africa and remarked that Africans should be let free to choose and cultivate their own home-grown development path (Meles, 2012). From this, the DDS of Ethiopia has strongly insisted on the truth that government is a dynamic development agent to bring about a systemic change. A systemic change is very impossible in the presence of merely one change driver to allocate resources; rather, it needs other complementarities - the state, market, and other forces of change. For that reason, the Ethiopian DDS has been placed on the multi-national federal contexts, democratization efforts, and coordinated state intervention in the case where the market fails to allocate resources efficiently (Gedion, 2015; Ohno, 2009).

\section{Ethiopian Democratic Developmental State: Blessings and Curses Incurred}

\section{A Glimpse on the Economic Blessings Entertained Under the Fledgling DDS}

Many internal and external forces witnessed that the DDS model installed in Ethiopia for about two decades has undergone remarkable economic transformation (Gedion, 2015; Weis, 2016). From the economic point of view, Ethiopia has become one of the countries that attempted to extricate chronic poverty at the fastest rate which declined from $45.5 \%$ in 2000 to $23.5 \%$ in 2016/17 (Belachew, 2019). Gross Domestic Product (GDP) rose from $\$ 30$ billion to $\$ 80.56$ billion in the span of the past eight years (2012-2020) with a steady increase in per capita income which now stands at $\$ 783$. This is more than a 50\% increase over the past 10 years. Life expectancy has also reached 66 years (Jay, 2019; Office of the Prime Minister-FDRE, 2019). Consequently, Ethiopia's Human Development Index (HDI) value for 2018 is 0.470 which still puts the country in the low human development category positioning it at 173 out of 189 
Teklie, T.B., The Status of Democratic Developmental State in Ethiopia: Is It Rolling Back ...

countries and territories. Between 2000 and 2018, Ethiopia's HDI value increased from 0.283 to 0.470, an increase of 65.8\% (United Nations Development Program [UNDP], 2019).

Ethiopian National Planning Commission (2015) indicated that the rapid and sustained doubledigit economic growth (10.9\%) recorded during the past 12 years was the success story of the DDS launched in Ethiopia. The government has achieved in the promotion of educational [where secondary and primary school enrollment reached 31\% and 85\% respectively in 2015] and health services [where 59/1000 live births under five die of different reasons] coverage in rural and urban areas though this fact shows much yet to be done concertedly (Office of the Prime Minister-FDRE, 2019). Particularly, the remarkable expansion of public universities from two in number in the 1980s to more than fifty today has been contributing strategically in augmenting human capitals. Pertaining to the physical infrastructures such as the construction of roads $\left(121,000 \mathrm{~km}^{2}\right)$, railways, electricity (44\%), and water supply (66\%), the government has also delivered encouraging outcomes (Office of the Prime Minister-FDRE, 2019). In connection, the industrial policy measures have brought rapid success in the industrialization process even though the manufacturing sector still constitutes 9.3\% of the GDP in 2018 (Hauge and Chang, 2019; Jay, 2019). The consecutive development plans initiated by the government have caused relative positive social transformations although each stage of implementation was accompanied by formidable challenges (UNDP, 2012; Eyob, 2017; Mulu and Daba, 2017; Clapham, 2018).

Moreover, Addisalem (2014) argued that the EPRDF's dual pursuits of promoting democracy and development have helped to restore relative peace, national consensus, and largely establish a strong state. It has been noted that the decade-long consistent economic performances have enabled the state to robustly resist some natural and manmade hazards hitherto (Yared, 2016). Thus, during the EPRDF's tenure, there was a relatively improved national consensus that poverty and backwardness are the embedded enemies and existential threats across the country. Among other things, the undergoing construction of Grand Ethiopian Renaissance Dam (GERD) is the most important precursor of the then efficacious roles of EPRDF in galvanizing the diversified people to a point of common national interest through consensus federalism (Tamrat, 2013). 


\section{Some Curses Encountered: Trade-off between Democracy and Development}

\section{Democratization Deficit}

Relying on the fact that the notion of a developmental state is adaptive and dynamic to changing circumstances in nature, there has been growing interest to apply it in a democratic scene (Edigheji, 2005). Nevertheless, some issues were experienced in the attempt of making democratization and developmental endeavors compatible in Ethiopia. The EPRDF led government has abused the civil and political rights enshrined in the constitution employing repressive electoral, terrorism, media, civil society, and other laws whereby the state is labeled as 'Not Free' (Freedom House, 2020). To the worst extreme, the miraculous economic achievement enjoyed under the guiding paradigm of DDS has forced the aid donors and advocacy establishments to overlook their inherent purpose of defending democratization and human rights in Ethiopia. They have accepted rather uncritically that the curtailment of democracy and human rights is a necessary and acceptable trade-off (Brown \& Fisher, 2020).

To illustrate, Bereket (2018) provided an instance that those citizens who ardently quest for good governance, fair benefit, popular participation, and justice in the occasionally prepared public forum have been forced to give their mobile numbers for the stage leaders thereby put them in the archives of blacklists in Tigrai. Those who speak for democracy and community development were branded as enemies of the ruling party and hence faced with subsequent life intimidations and unjust punishments. This worrying incident shows the truth that how much the democratic culture was [is] far from the ruling party's modus operandi and vivendi making the concept of DS malleable whereby the government organs have used and applied it in a very illusive suit. The government's courses of action to promote democratization and human rights have been rationalized and evaluated merely with a reference to the economic success of the developmental state. Pertinent to this, Gedion (2015) and the Government of Regional State of Tigray (2020) confirmed that the Ethiopian state was disreputable in democratization and political liberalization processes, disarming the alleged democratic institutions recognized by the constitution.

The opposition political parties competing in the state usually suggest that EPRDF's move to pursue DDS is aimed at renewing its legitimacy via the fake periodic election which enabled 
itself to stay in state power. They declared repeatedly that the five regular general elections conducted are not genuine and democratic but window dressing for the election outcomes was predetermined (Asnake, 2011; UNDP, 2012; Freedom House, 2020). By coincidence, Ohno (2009) had predicted that the natural political instability of developing countries and volatile EPRDF's developmental coalitions would appear as the sources of emerging challenges of the DDS of Ethiopia. In sum, as Endalcachew (2018) stated such detrimental effects as the perpetual erosion of the value of pluralism, human rights abuses, and entrenchment of a single party authoritarian rule have been faced during the power tenure of EPRDF.

\section{Unequal Distribution of Economic Benefits}

In the economic sphere, some costs were unarguably incurred by Ethiopian citizens. Worst of all, the rampant corruption in which PM Abiy ironically explained it as it was [is] the fifth organ of the government that has distorted the equitable distribution of national wealth among the people. Abiy justified that rule of corruption has been monolithically prevailed for the political leadership, where he was part of it, was plagued by lack of ability to create common dreams, excellence to control emotions, and reluctance to reconcile leadership skills (Abiy, 2019).

In parallel, Tefera (2019) has explicitly placed the prevailing economic fact in Ethiopia as attributed to oligarchization where the few party elites manipulated the economic decision in favor of their exclusive interests. Putting differently, carefully recognizing the political economy traditions entrenched throughout the last two decades, Weis (2016) has pointed that the Ethiopian state is characterized by vanguard capitalism, which combines the incompatible logic of democratic centralism and capitalist markets. After the shocking election result of 2005, EPRDF thus reclaimed its vanguard role in the fusing party, state, and market roles for economic transformation's sake. On the other hand, Bereket (2018) has witnessed that the EPRDF run government has unleashed to flourish plagues of predatory state and state capturing for its leadership part has itself submerged in the ocean of enlarging the respective pocket plundering the state's treasury. Bereket specifically stated that the political economy of rent-seeking has exposed government leaders to surrender their state apparatuses and machinery for very few giant capitalists so that accumulated mutually unfair wealth at the expense of the majority poor.

Most importantly, the economic and social developments achieved by the DDS model lack quality and proportionate distribution among the citizenry thereby the benefits were not 
materialized and not necessarily trickled down to reach the poor (Ayele, 2018; Hauge and Chang, 2019). In this regard, Abiy (2019) elaborated that high cost of living, unemployment (around 19\%), mismatch of saving and interest for investment, mismanagement of public projects, and weaknesses in the export sector and shortage of foreign exchange, budget deficit, sluggish structural transformation, contrabands, and illegal trades are the hallmarks of lack of quality and ethical development hitherto.

Irrefutably, the deceptive EPRDF's lexicon of "Developmental Capitalists" has produced a small class of capitalists who have exclusively concentrated on wealth establishing collusive interests with the ruling party elites. In support of this fact, Birhane Tsigab, a former member of the Central Committee of TPLF, revealed the embedded form of wealth accumulation and grand corruption within the ruling coalition and how that led to the decay of the coalition party (Birhane, 2020). Consequently, the political clientelism and patronages were widespread forcing EPRDF to change its top leaders in the hope of rectifying the past mistakes and building on its achievements (Government of Regional State of Tigray, 2020).

In this respect, Ayele (2018) further underlined that EPRDF has spoiled the inherent nature of DS and misapplied it in the process of state capture where both crony and political capitalism rooted in Ethiopia for two decades. Remarkably, the double-digit economic growth record reported by the government, International Monetary Fund (IMF), and World Bank (WB) were so much exaggerated for a number of ordinary citizens are still unable to afford even their minimum livelihood exemplifying what an elderly man from Oromia has said: "Our body is naked and our stomach empty, but the authorities keep telling us as that we are well dressed and fed!" (Ayele, 2018, p.1).

To the worst, few individuals wrongly argue that the DDS's path instead produced a fertile environment only for Tigrians to plunder the state's resources and exclusively accumulate infinite wealth (Young, 2020). However, the tangible fact is that few political and economic elites who are close to the political status quo irrespective of their ethnic grounds have been equally engaged in economic sabotages. The innocent people of Tigrai, however, remain poorer than the other nations, nationalities, and peoples of the state hitherto. As evidence, the poverty level of the National Regional State of Tigrai is about $29.6 \%$, the highest rate as compared to 
other regions, while the average rate at the national level is about $23 \%$ (United Nations Children's Fund [UNCIEF], 2020).

\section{Aggravating Factors for the Abortion of Democratic Developmental State \\ Ideological Division and Power Struggle within the Leadership}

"From a social-scientific viewpoint, an ideology is a more or less coherent set of ideas that provides a basis for organized political action, whether this is intended to preserve, modify or overthrow the existing system of power relationships" (Heywood, 2013, p.28). Ideologically speaking, in a typical DS the government leaders' common anthems and practices are attributed to ensuring development and eradicating poverty (Mkandawire, 2001). Along with this, ideal DDS needs internally cohesive, visionary, and committed leaders considered as the software who can effectively mobilize the human and material resources to realize the envisioned rapid economic development. Hence, the hegemonic development thinking is required to dominantly triumph throughout the party and state apparatuses (Gumede, 2009; Fesseha and Abtewold, 2017).

Normally, the political leadership part of a government puts the lion's fingerprint on the regular mission of a state in guiding the development agents to the required track strategically. Leaders are hopefully expected to be visionary and largely development-oriented particularly in states aspiring to be developmental (UN, 2011). In the case of Asian Tigers, the politicians were highly committed to the opening a fertile scene where the state bureaucracy actually ruled but the former ideally sat on the political chairs. Commonly speaking, the political leaders of these states were disciplined and courageous enough to let their respective countries catch up with the level of economic development where the West has reached (Fritz and Menocal, 2006).

Unfortunately, age-old intraparty sectarian power rivalries within the EPRDF fueled the protest movements dominantly in Oromia and Amhara regions precipitating the breakdown of collective leadership and ruling front in Ethiopia (Østebø and Tronvoll, 2020). To this end, TPLF, the founding member of EPRDF withdrew from Addis Ababa to Mekelle, the Tigray capital, and began coordinated opposition against the new administration. To the worst, rather than employing inclusive measures in the interest of political stability and administrative continuity, the new leadership of the federal government moved aggressively to the extent of removing 
TPLF leaders from key federal institutions (The International Institute for Strategic Studies[IISS], 2020).

Most worryingly, this time incumbent Ethiopian government has been categorically divided into two mutually inconsistent blocks, the leftists [the reform leaders] and rightists [the so-called inertia group]. This self-division of the government has resulted in ideological incompatibility and conflict of power interests among the government authorities ruling the same people and state. The first block is known as the Team-Lemma [named after the former Minister of Defense Force] that considers itself as a change agent engaged primarily in blackmailing what has been done by the deceased EPRDF - the dominant party which governed the state for about the last consecutive 28 years entirely. This block needs a change in the political economy status quo and seems ideologically submissive to the Neo-liberal recipes (IISS, 2020). Moreover, the new leadership condemns core tenets of EPRDF, revolutionary democracy, and democratic centralism, for they are timely irrelevant and democratic governance unfriendly (Ayele, 2018).

The second block of the government refers to TPLF [the rightist camp], one of the grand and founding members of EPRDF, which has still an insistent position on the perpetuation of the multi-national federation, revolutionary democracy, democratic and developmental state thinking. This segment of the government is a skeptic of the relevancy of Neo-liberalism arguing that it is dead to function in African existing contexts. TPLF's defense for DDS is an off-shoot of the architect of DDS, the late Prime Minister Meles Zenawi's position against the dead-end Neoliberal paradigm that African renaissance in general and Ethiopian in particular can only be possible if the respective states remain democratic and developmental in ideology and structure too (Meles, 2012). Discontented by the unconstitutional, unpredictable, and exclusive political reforms of PP's leadership, government officials from Tigrai on different occasions are arguing it is the DDS which assisted this country at least to reduce its level of abject poverty and change its image in a relative sense. Owing to this fact, the government of Tigrai is declaring for the consolidation of DDS and adequate ideological, structural, and institutional reforms are being undertaken thereon (Getachew, 2019).

Despite the fact that DS needs unanimous decisions and smooth relationships among the same government organs to realize the dreams of social transformation, ideological division and lack of internal harmony within the incumbent government are entrenched as daunting challenges in 
Ethiopia. During the EPRDF's ruling time, there had been an intra-party consensus at least within the political leadership that poverty is the existential threat and number one foe of the Ethiopian people. But now, in addition to the typical loopholes of the government officials to thoroughly and scientifically understand the nature of DDS, the recent ideological-level divisions and unlimited lust for power added fuels to the fire. The nascent DDS model was widely expected by several domestic and international communities to be full-fledged and ripen the already sown seeds of development and might change the economic image of the country. Regrettably, due to the leadership crises explained in the form of ruling party disintegration and political figures' disagreement, the state seems as it is going to embark from the scratch or be entangled in the vicious circle trap, the natural curse (Ayele, 2018).

\section{Structural and Institutional Profile of the Government: Fragile Bureaucracy}

In the successful DSs, capable and independent institutions have played irreplaceable roles in realizing rapid economic development (Edigheji, 2010). In Japan, for example, according to Chalmers Johnson, the independent pilot agency, Ministry of International Trade and Industry (MITI), composed of workers of best minds who have effectively and efficiently planned and executed developmental missions was the engine of the economic miracle (Johnson, 1982). This has happened as the relationship between the state and market, and the associated miraculous economic growths were institutionally founded (Haggard, 2015; Brown and Fisher, 2019).

Among other things, the role played by capable, effective, and autonomous state bureaucracy in the remarkable level of economic development attainted by the classical DS preoccupies the vital place (Mynes and Musamba, 2010). According to Evans, the highly selective meritocratic recruitment and long-term career rewards create commitment and a sense of corporate coherence. Nevertheless, state bureaucracy should withstand the pressures imposed by interest groups and at the same time genuinely be connected with the society to derive popular legitimacy concurrently-embedded autonomy (Evans, 1995).

In most of the LDCs in general and Africans in particular, the institutional capacity flaw of the civil service is taken as the major source of the political economy crises. African countries including Ethiopia have feeble, fragile, ineffective, and vulnerable institutions identified by lack of managerial, administrative, and technical skills (United National Conference on Trade and Development (UNCTAD), 2009). Cognizant of this truth, over the last three decades, many 
countries have been acquainting themselves with fundamental reforms in the structure and framework of their civil service sectors. Ethiopia, as part of its general political and economic restructuring programs, has undertaken comprehensive measures to restructure its bureaucracy (Chanie, 2001). Despite the reforms, it still lacks meritocratic and apolitical civil service in public sectors. In this respect, it has been argued that the power and strong organizational capabilities of the EPRDF were used to compensate for deficiencies of the bureaucracy (Oqubay, 2015).

In some cases, the bureaucrats in Ethiopia have been ethnically and politically affiliated in their routine public services delivery duties. This directly implies that public sectors are not independent of patronage and neo-patrimonial linkages whereby ultimately hindered the perpetuation of DDS. To mention a few, the land administration, customs and revenue authority, construction, telecommunication, trade, industry, and the like state sectors are found to be more susceptible to governance lacunas (Gedion, 2015; Jebena, 2015). Needless to say, the democratic institutions of the Parliament, Judiciary, Ethics and Anti-Corruption Commission, Ombudsman, media organization, and civil societies have constitutional recognition to exist and function for enhancing the democratic and developmental efforts. Conversely, their arms have been deliberately paralyzed to control the government (Mesgna, 2015; Transparency International (TI), 2015; Yohannes, 2019).

According to PM Abiy, one of the reasons why the attempt to build DS in Ethiopia for the last 27 years was not successful is the limitation to install capable institutions. The institutions on which the state has based have problems of intermingling the roles of party and government, lack of capacity and independence, and lack of adaptability to the social and economic changes (Abiy, 2019). In congruent, closely examining the institutional profile of the government, Clapham (2018) showed that clearly, Ethiopia ranks as one of the examples in Africa which applied developmental state beyond the East Asian experience so that meets Kelsall's criteria for what he terms 'Developmental Patrimonialism'. Thus, one cannot find a DS-friendly and compatible institution that can be considered as a pilot agency to direct and mobilize the state's activities in a coordinated way to achieve the grand goal of ensuring development and eradicating poverty under a democratic context (Alemayehu, 2019). 


\section{Current Political Dynamics: Changes and Continuities Followed}

\section{Reform Led Mushrooming Political Realities}

The rampant unequal distribution of wealth, lack of freedom, widespread unemployment, corruption, and self-enrichment on a grand scale coupled with the leadership crisis encountered in EPRDF has made a change not just desirable, but a necessity (Melaku, 2019). Particularly, in Amhara and Oromia regions, the violent youth protests and grievances had the form of ethnic conflicts for about three consecutive years (2015-18) consuming human lives and destructing development projects. Consequently, PM Abiy Ahmed succeeded in the ineffective leadership of Hailemariam Desalegn (IISS, 2020). Once PM Abiy Ahmed has controversially secured the state power, he promised that his government will unprecedentedly work to change the infamous deep-rooted conventional political economy of Ethiopia.

Initially, the new leadership camp has undertaken extraordinary courses of decisions to open up the previously narrow form of political and democratic space inviting several exiled political parties to come into their home state and become important stakeholders to ceiling the launched reform (Endalcachew, 2018). Thousands of political prisoners, particularly, members of opposition parties, journalists, bloggers, and activists who were considered criminals according to the then draconian Press, Electoral, and Anti-Terrorism Proclamations have been released on the legal measures of amnesty and pardon. The government has repealed repressive laws such as the Charities and Societies Proclamation and the Anti-terrorism Proclamation that had been used formerly since 2009 to paralyze local media, civil society, and opposition political parties (Amnesty International, 2020; Human Rights Watch (HRW), 2020). Moreover, a landmark peace deal despite its associated complicated issues was signed with Eritrea, important political and economic reforms were put in place, and corrupt officials and human rights abusers were prosecuted (Yohannes, 2019; HRW, 2020). Following the new leadership's ambitious official promises, many observers have hopefully expected the new leadership will promote and fasten Ethiopia's path towards democracy (De Waal, 2018; Mohamed et al., 2018).

In contrast to the aspirations of and trust rested on the new leadership, many responsible citizens of the state and other external actors have currently begun to doubt the internal strength and consistency of the change leaders. Among others, Abebe (2019) and Wendimu (2019) have plainly shown the incumbent government has no coherent, clear, and sustainable political and 
economic road maps which can scatter seeds to the alleged reform. Now, the government lacks thoughtful decisions and an agreed guiding philosophy through which the plagues of poverty, conflicts, and undemocratic culture could be dismantled persistently from the state (Mehari, 2019). Shockingly, the unifying glues of the multi-national federation and the constitution have been reminded subject to frequent violations.

Wendimu (2019) in his book entitled 'Beyond the Square' has scholarly debunked that the change-leaders two years' long rhetoric promises do not hold water in the sense that they failed to capture the existing state's thirsty for development, democracy, and peace. The change leaders have been rather aggressively working to defame the legacy of EPRDF led government in all possible words. Despite PM Abiy officially and repeatedly has been declaring that his 'Medemer' ideology emphasizes ameliorating the loopholes of the previously held dominant DDS model, his government has engaged in deconstructing what has been successfully achieved to start from scratch (Ibid).

The legacy of the undemocratic assumption of state paternalism and the old dictum of "I know best for you" has been explicitly manifested under the new leadership's behaviors (Abebe, 2019; Assefa, 2019). In this respect, it has been noted that it is difficult to denote 'Medemer' as whether it is incremental of the previous path or radical in nature. 'Medemer', an idea which seems as a surrogate of DDS notion, is merely limited to window dressing preach of the affirmative values of love, forgiveness, unity, fraternity, and synergy. These values are essential to ensure coordinated development, peace, and democracy, but they cannot stand alone in the absence of grand and overarching ideology which shows how to go forward to realize them. That is why the practice of the alleged change leaders is different from what they always proclaim publicly despite their claim that any reform is accompanied by path-dependent forces' resistances in nature (Wendimu, 2019). To this effect, ethno-nationalist forces argue that 'Medemer', the PP's guiding doctrine, is largely devoid of substance and may be a fig leaf over an emerging cult of personality (Reuters , 2019; IISS, 2020).

Unleashed from the unconstitutional and undemocratic decisions of the government, human and democratic rights violations have been faced by Ethiopian citizenry. Now, internal peoples' displacement (about 3 million), ethnic conflicts and balkanization, and mass killings by security forces, and arrest have become the new normal phenomenon of the state (Mehari, 2019; HRW, 
2020). There are no coordinated and institutionalized responses from the incumbent government towards such grave democratic culture deficits so that a number of people have doubt on the effectiveness of the government and predictability of the democratic system in the state (International Crisis Group (ICG), 2019; Amnesty International, 2020). In the worst case, vindicating the COVID-19 pandemic and interpreting the constitutional provisions, PP has postponed the general election formerly scheduled for August 2020 and inevitably resorted to some of the strong-arm tactics of its predecessors to prevent a loss at the ballot box. Both regional and federal government parliaments end their power tenure on October 10, 2020. Ethiopians speak threateningly of an inevitable civil war, state collapse, or both (Amnesty International, 2020). Unluckily, after the past two years' long reciprocal war of words and media propaganda undertaken between TPLF and PP, an actual war has been broken out in October 2020. The subsequent campaign of the Federal government to uphold the "Rule of Law" in Tigrai has changed its form into unprecedented war. Owing to the war, the humanitarian crisis is being experienced by millions of civilians and several people have been exposed to displacements, killings, organized plundering, and hunger.

\section{Burgeoning Economic Policy-Oriented Confusions}

After the coming of Prime Minister Abiy Ahmed on April 2, 2018, to the state power, the Ethiopian government has unveiled a new economic reform blueprint, named "Homegrown Economic Reform Agenda", with a major aspiration to unlock the country's development potentials. The newly introduced initiative, among other things, outlined macroeconomic, structural, and sectoral reforms that are said to pave the way for job creation, poverty reduction, and inclusive growth (Office of the Prime Minister, 2019; Xinhua, 2019). In the name of "Home Grown" economic policy reform, the new leadership has officially embarked to conform to the typical recipes of International Financial Institutions (IFIs). In fact, the so-called "Home Grown" economic policy has failed to reflect and understand the real and structural economic problems defined in terms of economic and social infrastructure, research capability, technological knowhow and human resource development, and socio-political organization that the country has at home. In a nutshell, it prescribes a solution without identifying the root causes of the problem around which remedial policies should have been proposed (Alemayehu, 2019). 
Shockingly, without making adequate study, the commanding heights of the economy and sources of the state capacity including the Ethio-Telecom, financial sectors, power, and Ethiopian Airlines which were previously under the state control, are now going to be privatized to either foreign or domestic companies [if any] in the hope of securing foreign capital for development (Sara, 2019). Nevertheless, Belachew (2019) here recommends the state both as regulator and, in some instances, as an active player in developmental projects, which is still needed with some adjustment only on its highly centrist approach.

Deferred from the age-old EPRDF led government experience, Abiy's leadership has exhibited policy change in line with long-standing recommendations from the WB and IMF which boosted financial support for Ethiopia in subsequent months. In late 2019, the IMF announced a preliminary agreement with Abiy's administration for a loan of nearly $\$ 3$ billion that demanded gradual liberalization of the exchange-rate regime, among other conditions. At the same time, the government restarted talks to join the World Trade Organization (Jay, 2019; IISS, 2020). This proves the fact argued by Belachew (2019) that Ethiopian economic policy has been in constant fluidity as the regimes change.

After a closer examination of the reformists' leadership in EPRDF, Alex De Waal has hence the doubt that the Ethiopian state could be the political marketplace of some other foreign state and non-state actors. This implies that the national interest of the Ethiopian state is being overlooked. This is because the reform lacks domestic institutional readiness and succinct strategy of statedirected economic growth, commitment to pro-poor welfare policies, and nature of the state institutions (De Waal, 2018). Thus, once critically analyzing the prevailing political and economic situations of the state, Mehari (2019) has scholarly put five possible scenarios which are consensus federalism, establishing a transitional government, prevailing dictatorship, confederate Ethiopia, or fragmentation/disintegration.

Despite PM Abiy has shown in his book entitled 'Medemer' that there are three causes for the fracture of the Ethiopian economic system which include inadequacy of market, government, and system, his government still becomes unable to fill them adequately. He also noted healthy economic development will be achieved with the participation of the government, private sector, non-governmental organizations (NGOs), and educational institutions (Abiy, 2019). Put differently, the already dead EPRDF led democratic developmental state had identified that its 
social base was relayed on the political coalitions of small landholder farmers, laborers, and urban dwellers mainly taking effective experiences from Scandinavians and Japan (Meles, 2012; Kidanemariam, 2014; Tapscott et al., 2018). Here, a vivid change in the ideological social base has also been observed.

On the other hand, the PM repeats EPRDF's approach to achieving development through Agricultural Development Led Industrialization (ADLI). He says economic development is the prerequisite for peace and security of Ethiopia echoing EPRDF's policy of DS. In this vein, the PM's perspective of economic development seems not different from that of EPRDF. In his 'Medemer' book, the PM stated that Ethiopia should pursue youth oriented-economic development for the jobless youth to maintain the peace and security of the country. In addition, he confirms agriculture is the backbone of the economy which needs to be modernized and market-focused. It seems that PM Abiy is trying to sell EPRDF's ideas by rebranding and repackaging them (Assefa, 2019). Relying on these facts, it remains safe to argue the incumbent government lacks internal coherence and faces confusions of ideological emphasis which may in the long run costs the state a lot.

In the 2019-World Economic Forum, as a clear manifestation of ideological confusions of the incumbent government, PM Abiy has boldly appreciated the economic performance achieved by EPRDF and delivered his speech in the languages of the developmental state formerly used by his predecessor PM Meles (Jay, 2019). Nevertheless, in practical words, the development partners of Abiy's government tend to be a western world dominated. Now, China, the former development and political economy-ally of the Ethiopian government appears to have fewer places in the current government of Ethiopia. Anyway, the IMF had forecasted per capita GDP growth to drop to $5.5 \%$ in 2020 due to COVID-19 (IISS, 2020). The ongoing war within the state might worsen the economic crisis incurred too. Depending on the above realities, one can infer that the two-decades-long launched DDS has reached its pinnacle of premature death and subsequent replacement by Neo-liberal orientations in the state.

\section{Conclusion and Recommendation}

Ethiopia has been serving as the laboratory room for different politico-economic ideologies. The deceased EPRDF led government has acquainted Ethiopia with the DDS model on the fact that both democracy and development are equally important existential values. Many domestic and 
international observers hence witnessed that the DDS development path has made Ethiopia paint rosy economic pictures on the global community's eye. The trade-off between democracy and economic development has been considered as a tolerable cost. Principally, the ideological split, needless lusts for power in the political leadership, and the flimsy institutions have in tandem triggered the abortion of the embryonic but far-sighted DDS. Explicitly, the new leadership has brought a shift in ideology to conform itself to the Neo-liberal recipes although it lacks selfharmony and consistency. Nevertheless, some argue that the new leadership appears to regurgitate the footsteps of its predecessor EPRDF rebranding its infamous legacy. It is suggested that the reform desperately seeks coordinated political and economic road maps to transform the state into the democratic scene and development avenues. In sum, the reformist group should tackle its leadership lacunas via consistent national dialogue to that they secure positive synergy and rescue the state from its natural destiny of vicious circle trap.

\section{References}

Abebe, T. (2019). Ethiopian politics: From where to where. Addis Ababa: Mankusa Printing House.

Abiy, A. (2019). $\sigma^{\square} \rho{ }^{\circ} \mathcal{L}($ Medemer) (Amharic Edition). Addis Ababa: Tsehai Publishers.

Gebremariam, M. F., Bayu, M. A. (2017). Ethiopia: A democratic developmental state ? ILIRIA International Review 7(2): 10-26.

Balema, A. A. (2014). Democracy and economic development in Ethiopia. New Jersey: The Red Sea Press.

Geda, A. (2005). The political economy of growth in Ethiopia. Retrieved May 03, 2020, from http://www.alemayehu.com/AA\%20Recent\%20Publication/ Growth_CambChap_Sept2006.pdf

Geda, A. (2005). 'Macroeconomic performance in post-reform Ethiopia' Journal of Northeast African Studies 8(1): 159-185.

Geda, A. (2019). Ethiopia's "homegrown" reform: If the diagnosis is not right, it may end-up a wish list. Addis Ababa: AAU. Retrieved May 03, 2020, from https://www.reseachgate.net/publication335972270

Altenburg, T. (2010). Industrial policy in Ethiopia: Discussion paper. German Development Institute .

Amaha, D. T. (2012). The impact of policies and strategies on Ethiopia's development challeges. Pretoria: University of South Africa.

Amnesty International. (2020). Beyound law enforcement: Human rights violation by Ethiopian security forces in Amhara and Oromia. London: Amnesty International Ltd.

Asnake, K. (2011). Narratives of developmentalsim and development in Ethiopia. Addis Ababa University: PP.1-14. 
Assefa, L. A. (2019). Satenawnews. Retrieved February 19, 2020, from https://www.satenaw.com/book-review-medemer-a-book-by-dr-abiy-ahmed/

Ayele, G. (2018). Commentary: What is happening to EPRDF'S developmental state? Addisstandard, Addis Ababa, Ethiopia. Retrieved February 19, 2020, from https://addisstandard.com/commentary-what-is-happening-to-eprdfs-developmental-state/

Bagchi, A. K. (2000). The past and the future of the developmental state. Journal of WorldSystems Research 6(2): 398-442.

Belachew, M. (2019). Economic analysis: Ethiopia's developmental state: Dead or alive? Addis Standard. Addis Ababa. Retrieved February 19, 2020, from https://addisstandard.com/economic-analysis-ethiopias-developmental-state-dead-oralive/

Bereket, S. (2018). Rebirth of Ethiopia from a cross roads (Translated From Amharic Version). Angkor Publishers Pvt.Ltd, India.

Bichaka, F. (1992). Rent seeking behaviors of Ethiopian rulers as a constraint for the economic developmennt of Oromo people . Oromo Commentary.

Bigman, D. (2007). Globalization and the least developed countries: Potentials and pitfalls. UK: Bidless Ltd KIngs Lynn.

Birhane, T. (2020). Twin roads' conversation . Addis Ababa: Fareast Publishing Trading.

Bolesta, A. (2007). China as a developmental state. Montenegrin Journal of Economics No 5: 106-108.

Brown, S., \& Fisher, J. (2020). Aid donors, democracy and the developmental state in Ethiopia. Democratization 27(2): 185-203.

Chanie, P. (2001). The challenges of civil service reform in Ethiopia: Initial observations.

Eastern Africa Social Science Research Review (17): 79-102.

Chris Tapscott, T. H.D. (2018). The democratic developmental state: North-south perpective. Stuttgart, Germany: CROP International Poverty Studies .

Clapham, C. (2018). The Ethiopian developmental state. Third World Quarterly 39(6):11511165.

Creswel, J. W. (2009). Research design: Qualitative, quantitative and mixed methedos. London: SAGE Publications. Inc.

Edigheji, O. (2005). A democratic developmental state in Africa? Johannesburg, South Africa: Centre for Policy Studies.

Edigheji, O. (2010). Constructing democratic developmental state in South Africa: Potentials and challenges. Cape Town: HSRC Press.

Endalcachew, B. (2018). Developmental state of Ethiopia : Reflections on the benefits obtained and costs incurred. Ethiopian Journal of the Social Sciences and Humanities 14 (2): 7292.

Evans, P. B. (1995). Embedded autonomy: States and industrial transformation in the United Kingdom. West Sussex: Princeton University Press.

Eyob, G. B. (2018). The carrot and stick of Ethiopian democratic developmentalism: Ideological, legal and policy frameworks, 62-86. In Tapscott Chris, Halvorsen Tor \& Rosario Teresita Cruz-del (eds.). The democratic developmental state: North-south perspectives. Germany: Ibidem Presss.

Fantini, E. (2013). Developmental state, economic transformation and social diversification in Ethiopia. ISPI (Analysis No. 163): 1-7. 
Fesseha, M., \& Bizuayehu, D. (2017). In defense of Ethiopia's adoption of "democratic developmental state" - issues and challenges. Üniversitepark Bülten 6(2): 66-73.

Freedom House. (2020). Freedom in the world-2020 - Ethiopia .

Fritz, V., \& Menocal, A. R. (2006). (Re) building developmental states: From theory to practice. Overseas Develpment Institute: Working Paper.

Gedion, J. G. (2005). An African developmental state: Ethiopia's emergent experience. Regional Conference on Building Democratic Developmentalstate for Economic Transformation in Sothern Africa, pp.1-35.

Getachew, R. (2019). Current issue. (T. Television, Interview)

Gumede, W. (2009). Delivering the democratic developmental state in South Africa: Development planning division. Working Paper Series No 9.

Haggard, S. (2015). The developmental state is dead: Long live the developmental state! Researchgate, pp. 40-66.

Hauge, J., \& Chang, H. J. (2019). The concept of a 'developmental state' in Ethiopia: Part.vi. In Fantu Cheru, Christopher Cramer (eds.). The Oxford Handbook of the Ethiopian Economy. Oxford: OUP.

Heywood, A. (2013). Politics. New York: The Palgrave Macmillan.

Human Rights Watch(HRW). (2020). World report events of 2019. USA: Human Rights Watch. International Crisis Group (ICG). (2019). Keeping Ethiopia's transition on the rails. Brussels, Belgium : International Crisis Group.

Jay, S. (2019). The new scramble for Ethiopia. Retrieved February 12, 2020, from https://www.jacobinmag.com/2019/06/ethiopia-abiy-ahmed-meles-zenawi?

Jebena, B. A. (2015). Ethnic federalism and democratic developmental state in Ethiopia: Some points of contradictions. International Journal of Political Science and Development 3(7): 291-300.

Kidanemariam, B. H. (2014). Democratic developmental state. National Graduate Institute for Policy Studies. Retrieved February 12, 2020, from https://www.grips.ac.jp/forum/IzumiOhno/lectures/2014_Lecture_texts/Lec7_DDS_Kidu .pdf

Lidetu, A. (2020). Ethio-forum. (T. Television, Interview)

Mehari, M. T. (2019). Indepth-analysis: Can Ethiopia make the transit to stability. Addis Ababa, Ethiopia. Retrieved February 12, 2020, from https://addisstandard.com/in-depth-analysiscan-ethiopia-make-the-transit-to-stability/

Melaku, H. (2019). Ethiopian insight. Retrieved February 12, 2020, from http://www. ethiopiainsight.com

Meles, Z. (2012). States and markets: Neoliberal limitation and the case for developmental state. DOI:10.1093/acprof:oso/9780199698561.003.0005

Mesgna, G. (2015). Challenges and prospects of building the developmental state in Africa: A comparative study of Botswana and Ethiopia. MA Thesis. Addis Ababa: AAU.

Mkandawire, T. (2001). Thinking about developmental states in Africa. Cambridge Journal of Economics 25(3): 289-313.

Salih, M., Eshete, A., Assefa, S. (2018). Reflections on expanding Ethiopia's democratic space: Aspirations, opportunities, choices. Addis Ababa: Friedrich-Ebert-Stiftung.

Musamba, P. M. (2010). The developmental state in Africa: Problems and prospects . University of Duisburg-Essen: Institute for Development and Peace. 
Teklie, T.B., The Status of Democratic Developmental State in Ethiopia: Is It Rolling Back ...

Mathebula, N. E. (2016). An impossible developmental state in the South African context: A true reflection of the Asian Tigers? Bangladesh e-journal of sociology 13(1): 46-55.

National Planning Commision. (2015). Growth and Transformation Plan II (2015/16-2019/20). Addis Ababa, Ethiopia .

Office of the Prime Minister. (2019). A homegrown economic reform agenda: A path way to prosperity. Addis Ababa, Ethiopia .

Ohno, K. (2009). Ethiopia: Political regime and development policies. Tokyo: Graduate Institute for Policy Studies (GRIPS). Presented at Policy Dialogue on Industrial Development in Ethiopia, Addis Ababa.

Oqubay, A. (2015). Made in Africa: Industrial policy in Ethiopia. Oxford: Oxford University Press.

Pillay, P. (2002). The role of the state in economic development in southern Africa: Dialogue on globalization. Berlin: Department for Development Policy, Friedrich-Ebert-Stiftung

Rapley, J. (2010). Uderstanding development: Theory and practice in the third world. New Delhi: Lynne Reinner.

Reuters. (2019). Ethiopia's ruling coalition agrees to form single party ahead of 2020 vote. Reuters.

Routley, L. (2014). Developmental states in Africa? A review of ongoing debates and buzzwords. Development Policy Review 32(2): 159-177.

Sara, M. (2019). Abiy Ahmed's 'Medemer' reforms: Can it ensure sustainable growth for Ethiopia and what are the challengesfacing the new government? Policy Center for the New South (PB-19/08): 1-9.

Solomon, I. (2007). Tigrai: The agony and the ecstasy. Ethiopia: Berhanena Selam Printing.

Stiglitz, J. E. (1998). Towards a new paradigm for development: Startegies, policies and processes. Geneva: UNCTAD .

Tamrat, D. D. (2013). Emergence of democratic developmental state in Africa: The experience from Ethiopia. DOI: https://dx.doi.org/10.2139/ssrn.2329040

Tefera, G. N. (2019). The party that consumes the state: The rise of oligarch in post 1991 Ethiopia. Rotterdam: Legatron Electronic Publishing.

Østebø T. \& Tronvoll K. (2020). Interpreting contemporary Oromo politics in Ethiopia: An ethnographic approach. Journal of Eastern African Studies 14(4): 613-632. DOI: 10.1080/17531055.2020.1796255

TGE. (1991). Peaceful and democratic transitional conference of Ethiopia: Negarit Gazeta. Addis Ababa, Ethiopia .

The International Institute for Strategic Studies (IISS). (2020). Ethiopia's factional politics. Strategic Comments 26 (2):10-12.

Tigrai, G. O. (2020). Memorandom on averting the looming constitutional and political crisis in Ethiopia. Mekelle: The Government of Regional State of Tigray.

Transparency International (TI). (2015). Corruption perception index. Berlin: TI

UN. (2011). Governing development in Africa - The role of state in economic transformation. Addis Ababa: United Nations Economic Commission for Africa.

Tsegaye R. and Sehen B. (2012). Democratization in a developmental state: The case of Ethiopia: Issues, challenges and prospects. Ethiopia: Governance and Human Rights Unit, UNDP.

HDR. (2019). Beyond income, beyond averages, beyond today: Inequalities in human development in the $21^{\text {st }}$ century. New York: UNDP. 
United Nationa Conference on Trade and Development (UNCTAD). (2009). The least developed countries report: The state and development governance. New York: United Nations.

Waal, A. D. (2018). The future of Ethiopia: Developemntal state or the political market place. World Peace Foundation, pp.1-19.

Weis, T. (2016). Vanguard capitalism: Party, state and market in the EPRDF's Ethiopia. (Doctoral dissertation, University of Oxford).

Weldeabrha, N. (2014). Democratic developmental state from local governnace perspective: The case of Hawzen Woreda,Masters Thesis. Mekelle University, Mekelle.

Wendimu, A. (2019). Beyond the Square. Addis Ababa.

White, G. (2006). Towards a democratic developmental state. Institute of Development Studies Bulletin 37(4): 60-70.

Xinhua. (2019, 09 10). Roundup: Ethiopia's newly unveiled economic reform aims to unlock major dev't potentials. Retrieved 02 20, 2020, from http://www.xinhuanet.com/english/2019-09/10/c_138381691.htm

Yared, G. (2016). Ethiopia continues to grow amdist challenges. Addis Ababa: Ethiopian Herald News Paper .

Yohannes, G. (2019, 12 18). Aljazeera. Retrieved January 7, 2020, from https://www.aljazeera.com/indepth/opinion/abiy-ahmed-prosperity-party-good-newsethiopia

Young, J. (2020, May 23). Ethio-forum. (T. Television, Interview) 